\title{
Regulation of the Maintenance of Peripheral T-Cell Anergy by TAB1-Mediated p38 $\alpha$ Activation
}

\author{
Kozo Ohkusu-Tsukada, ${ }^{1}$ Norio Tominaga, ${ }^{1,2}$ Heiichiro Udono, ${ }^{1,3}$ and Katsuyuki Yui ${ }^{1 *}$ \\ Division of Immunology, Department of Translational Medical Sciences, ${ }^{1}$ and Division of Medical Virology, Department of \\ Molecular Microbiology and Immunology, ${ }^{2}$ Graduate School of Biomedical Sciences, Nagasaki University, \\ Nagasaki 852-8523, and Laboratory for Immunochaperones, RIKEN Research Center for Allergy \\ and Immunology, Tsurumi-ku, Yokohama, Kanagawa 230-0045, ${ }^{3}$ Japan
}

Received 15 January 2004/Returned for modification 24 February 2004/Accepted 18 May 2004

\begin{abstract}
In anergic $\mathbf{T}$ cells, T-cell receptor (TCR)-mediated responses are functionally inactivated by negative regulatory signals whose mechanisms are poorly understood. Here, we show that $\mathrm{CD} 4^{+} \mathrm{T}$ cells anergized in vivo by superantigen Mls-1 ${ }^{\text {a }}$ express a scaffolding protein, transforming growth factor $\beta$-activated protein kinase 1-binding protein 1 (TAB1), that negatively regulates TCR signaling through the activation of mitogenactivated protein kinase $\mathrm{p38} \alpha$. TAB1 was not expressed in naive and activated $\mathrm{CD4}^{+} \mathrm{T}$ cells. Inhibition of p38 activity in anergic $T$ cells by a chemical inhibitor resulted in the recovery of interleukin 2 (IL-2) and the inhibition of IL-10 secretion. T-cell hybridoma 2B4 cells transduced with TAB1-containing retrovirus (TAB1$2 B 4$ cells) showed activated $\mathbf{p 3 8} \alpha$, inhibited extracellular signal-regulated kinase (ERK) activity, culminating in reduced IL-2 levels and increased IL-10 production. The use of a p38 inhibitor or cotransfection of a dominant-negative form of p38 in TAB1-2B4 cells resulted in the recovery of ERK activity and IL-2 production. These results imply that TAB1-mediated activation of $\mathrm{p38} \alpha$ in anergic $\mathrm{T}$ cells regulates the maintenance of T-cell unresponsiveness both by inhibiting IL-2 production and by promoting IL-10 production.
\end{abstract}

Anergy is a tolerance mechanism in which lymphocytes are functionally inactivated following an antigen encounter but remain alive for an extended period of time. $\mathrm{T}$ cells become anergic after incomplete activation in vitro (33). Such anergic $\mathrm{T}$ cells display impaired tyrosine phosphorylation of the T-cell receptor (TCR) $\zeta$ chain and recruitment of ZAP-70 (36). Anergic $\mathrm{T}$ cells have a defect in the activation of Ras (11) and its downstream mitogen-activated protein kinases (MAPKs), extracellular signal-regulated kinase (ERK) and c-Jun $\mathrm{NH}_{2}$-terminal kinase (JNK) $(10,19)$, culminating in the low activity of the AP-1 response element and defects in interleukin 2 (IL-2) synthesis (17). In addition to these defects in TCR signaling, active negative signaling pathways play a role in maintaining T-cell anergy. Activated Rap- 1 in anergic T cells antagonizes Ras activity, resulting in reduced Raf-1 protein kinase activity (5). An increase in the level of the cyclic AMP response element-binding protein/cyclic AMP response element modulator complex in anergic $\mathrm{T}$ cells results in the repression of IL-2 transcription (28). Furthermore, the presence of some dominant molecules that inhibit anergic T-cell activation has been suggested (41). Searches for anergy-associated genes have identified $T o b$ and a gene related to anergy in lymphocytes $(G R A I L)$ as genes expressed during the early phase of T-cell anergy induction $(2,43)$. Forced expression of $T o b$ in $\mathrm{T}$ cells can repress $\mathrm{T}$-cell proliferation and cytokine transcription. The expression of GRAIL in T cells limits cytokine production in a manner that is dependent on E3 ubiquitin ligase activity. Macian et al. used microarrays to identify several sets of anergy-

\footnotetext{
* Corresponding author. Mailing address: Division of Immunology, Department of Translational Medical Sciences, Graduate School of Biomedical Sciences, Nagasaki University, 1-12-4 Sakamoto, Nagasaki 852-8523, Japan. Phone: 81-95-849-7070. Fax: 81-95-849-7073. E-mail: katsu@net.nagasaki-u.ac.jp.
}

associated genes that are expressed in a T-cell clone upon ionomycin treatment, which can induce clonal anergy (21). These genes are induced in an NFAT1-dependent manner, but their function has yet to be defined.

$\mathrm{T}$ cells expressing specific $\mathrm{V} \beta$ chains can be rendered anergic by inoculation of mice with a superantigen (30). These in vivo-anergized $\mathrm{T}$ cells display defects in tyrosine phosphorylation of the TCR $\zeta$ chain and subsequent recruitment of ZAP-70 $(4,22)$ similar to $\mathrm{T}$ cells anergized in vitro. In vivo-anergized $\mathrm{T}$ cells, as opposed to in vitro-anergized T cells, can produce IL-10, a cytokine that inhibits the T-cell response. Such cells can function as regulatory $\mathrm{T}$ cells $(8,37)$. Their unresponsiveness is maintained both by their autonomous anergy and by suppression mediated by inhibitory cytokines $(3,23)$.

Here, we investigated the MAPK pathways involved in the maintenance of peripheral CD4 ${ }^{+}$-T-cell anergy by using TCR

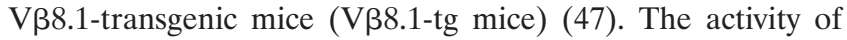
p38 kinase was augmented in anergic $\mathrm{CD}^{+} \mathrm{T}$ cells, and a scaffolding protein, transforming growth factor $\beta$-activated protein kinase 1 (TAK1)-binding protein 1 (TAB1), that can activate p38 $\alpha$ (34) was expressed. The treatment of anergic T cells with an inhibitor of $\mathrm{p} 38$ resulted in the partial recovery of ERK activation and IL-2 secretion after TCR stimulation and in the inhibition of IL-10 secretion. The forced expression of TAB1 in a T-cell hybridoma resulted in the activation of $\mathrm{p} 38$, culminating in the inhibition of ERK, in the reduction of IL-2 production, and in the up-regulation of IL-10 synthesis after TCR stimulation. These results imply that TAB1 is a key regulatory molecule involved in maintaining T-cell anergy in vivo.

\section{MATERIALS AND METHODS}

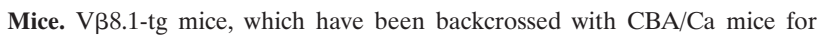
more than 10 generations (47), were maintained in the Laboratory Animal Center for Research at the Nagasaki University School of Medicine. OT-II mice 
were provided by W. R. Heath (The Walter and Eliza Hall Institute of Medical Research, Parkville, Victoria, Australia) as described previously (42). Transgenic mice were used when they were between 8 and 12 weeks old. CBA/J $\left(\mathrm{H}-2^{\mathrm{k}}\right.$ Mls- $1^{\mathrm{a}}$ ) mice were obtained from Charles River (Yokohama, Japan). The review board of the Nagasaki University School of Medicine gave approval for the animal studies.

Induction of T-cell anergy and cell culture. T-cell anergy was induced in VB8.1-tg mice as previously described (48). T-cell-depleted spleen cells $(1.5 \times$ $10^{7}$ ) were prepared by treatment of CBA/J spleen cells with a combination of anti-CD4 (GK1.5), anti-CD8 (3.155), and anti-Thy-1.2 (30H12) monoclonal antibodies (MAbs) plus complement and were inoculated intravenously into VB8.1-tg mice. At 12 to 18 days after injection, $\mathrm{CD}^{+}{ }^{+} \mathrm{T}$ cells were prepared from inguinal, popliteal, brachial, axillary, and mesenteric lymph nodes of untreated or superantigen-inoculated mice. $\mathrm{CD}^{+}{ }^{+} \mathrm{T}$ cells were purified $(92$ to $98 \%$ ) by treatment of lymph node cells with an anti-CD8 MAb (3.155) plus complement, followed by nylon wool column enrichment, or were purified $(>98 \%)$ by use of BD IMag-anti-mouse CD4 MAb GK1.5 (BD Biosciences PharMingen, San Diego, Calif.).

$\mathrm{CD}^{+} \mathrm{T}$ cells $\left(5 \times 10^{4} /\right.$ well $)$ were treated with SB203580 (1 to $\left.10 \mu \mathrm{M}\right)($ a gift from SmithKline-Beecham Co.) or PD98059 (10 $\mu \mathrm{M})$ (Cell Signaling, Beverly, Mass.) for $2 \mathrm{~h}$ at $37^{\circ} \mathrm{C}$ in $5 \% \mathrm{CO}_{2}$. In some experiments, $150 \mu \mathrm{l}$ of medium was removed from each well and replaced with $200 \mu \mathrm{l}$ of fresh medium, resulting in a fivefold dilution of the inhibitors at the end of the pretreatment.

After mixing, cells were transferred to wells of a flat-bottom 96-well plate coated with an anti-TCR MAb (H57; 1 to $10 \mu \mathrm{g} / \mathrm{ml}$ ). After $72 \mathrm{~h}$ of culturing, proliferation was assessed by using a terminal pulse of $18.5 \mathrm{kBq}$ of $\left[{ }^{3} \mathrm{H}\right]$ thymidine for $8 \mathrm{~h}$. The proliferative response of $\mathrm{CD}^{+} \mathrm{T}$ cells to $\mathrm{Mls}-1^{\mathrm{a}}$ or $\mathrm{Mls}-1^{\mathrm{b}}$ was evaluated by culturing $\mathrm{CD} 4^{+} \mathrm{T}$ cells $\left(5 \times 10^{4}\right)$ with mitomycin C-treated CBA/J or $\mathrm{CBA} / \mathrm{Ca}$ spleen cells $\left(0.03 \times 10^{5}\right.$ to $\left.1 \times 10^{5}\right)$. Staining of cells with 5,6 carboxyfluorescein diacetate succinimidyl ester (CFSE) was performed as previously described (20). After culturing, cells were stained with a phycoerythrinanti-CD4 MAb (eBioscience, San Diego, Calif.) and analyzed by using a FACScan (Becton Dickinson and Co., Mountain View, Calif.).

Th1 and Th2 cells were prepared as previously described (42). Briefly, CD4 ${ }^{+}$ $\mathrm{T}$ cells $\left(10^{5} / \mathrm{ml}\right)$ purified from OT-II mice were cultured with mitomycin Ctreated C57BL/6 spleen cells $\left(4 \times 10^{5} / \mathrm{ml}\right)$ and ovalbumin (amino acids 323 to 339) peptide $(10 \mu \mathrm{M})$ for 7 days. Th1 mixtures contained IL-2 $(20 \mathrm{U} / \mathrm{ml})$, IL-12 (20 ng/ml), and anti-IL-4 MAb 11B11 $(10 \mu \mathrm{g} / \mathrm{ml})$. Th2 mixtures contained IL-2 (20 U/ml), IL-4 (100 U/ml), anti-gamma interferon MAb R4-6A2 (15 $\mu \mathrm{g} / \mathrm{ml})$, and anti-IL-12 MAb C17.8 $(10 \mu \mathrm{g} / \mathrm{ml})$.

Western blot analysis. CD $4^{+} \mathrm{T}$ cells $\left(3 \times 10^{5}\right)$ were plated on an anti-TCR MAb-coated 96-well plate, centrifuged briefly, and cultured for 5 to $90 \mathrm{~min}$. At the end of the culture period, cells from four wells were combined and resuspended in $50 \mu \mathrm{l}$ of lysis buffer A (1\% Triton X-100, $10 \mathrm{mM}$ Tris- $\mathrm{HCl}$ [pH 7.4], $150 \mathrm{mM} \mathrm{NaCl}, 1 \mathrm{mM}$ EDTA, $1 \mathrm{mM}$ phenylmethylsulfonyl fluoride). After centrifugation, the lysate was size fractionated by sodium dodecyl sulfate (SDS)$12.5 \%$ polyacrylamide gel electrophoresis (PAGE) and transferred to a polyvinylidene difluoride membrane by electrotransfer. The membrane was incubated in blocking buffer (Tris-buffered saline containing 5\% skim milk and $0.1 \%$ Tween 20) and then probed with anti-phospho-ERK, anti-ERK, anti-phospho-JNK, anti-JNK, anti-phospho-p38, and anti-p38 antibodies (Cell Signaling), anti-p27/ kip1 antibody (Transduction Laboratories, San Diego, Calif.), anti-TAB1 antibody (Santa Cruz Biotechnology, Santa Cruz, Calif.), or antiactin antibody (Sigma-Aldrich, St. Louis, Mo.). After washing, the membrane was incubated with horseradish peroxidase (HRP)-conjugated anti-rabbit immunoglobulin antibody or with biotin-conjugated anti-mouse immunoglobulin antibody, followed by HRP-streptavidin. Proteins were visualized by using an ECL kit according to the manufacturer's protocol (Amersham Biosciences Corp., Piscataway, N.J.).

Recombinant TAB1 protein was produced in Escherichia coli. A fragment of cDNA corresponding to human TAB1 (amino acids 1 to 312 ) (TAB1 $1-312$ ) was amplified by PCR with human TAB1 cDNA (kindly provided by K. Matsumoto, Nagoya University, Nagoya, Japan) (34), subcloned into pQE32, expressed in $E$. coli, and purified as previously described (44). We confirmed the specificity of the anti-TAB1 antibody by absorption with this recombinant $\mathrm{TAB} 1_{1-312}$ protein.

In vitro kinase assays. Cells were lysed in ice-cold lysis buffer $\mathrm{B}(1 \%$ Triton $\mathrm{X}-100,10 \mathrm{mM}$ Tris [pH 7.5], $150 \mathrm{mM} \mathrm{NaCl}, 2 \mathrm{mM}$ EGTA, $50 \mathrm{mM} \beta$-glycerophosphate, $2 \mathrm{mM} \mathrm{Na}_{3} \mathrm{VO}_{4}, 10 \mathrm{mM} \mathrm{NaF}, 1 \mathrm{mM}$ dithiothreitol, $1 \mathrm{mM}$ phenylmethylsulfonyl fluoride, $10 \mu \mathrm{g}$ of leupeptin/ml). After centrifugation, the lysate was precipitated with anti-ERK1 or anti-p38 $\alpha$ antibody and protein A-Sepharose, washed three times with lysis buffer $\mathrm{B}$, and washed twice with kinase buffer (20 mM HEPES [pH 7.5], $20 \mathrm{mM} \mathrm{MgCl} 2,20 \mathrm{mM} \mathrm{MnCl}_{2}, 2 \mathrm{mM}$ dithiothreitol, 25 $\mathrm{mM} \beta$-glycerophosphate, $100 \mathrm{nM} \mathrm{Na} \mathrm{VO}_{4}$ ). Samples were resuspended in $18 \mu \mathrm{l}$ of kinase buffer containing $1 \mu \mathrm{g}$ of maltose-binding protein or $1 \mu \mathrm{g}$ of ATF2 peptide (Upstate Biotechnology, Lake Placid, N.Y.) in the presence of $20 \mu \mathrm{M}$ cold ATP and $0.72 \mathrm{MBq}$ of $\left[\gamma^{-32} \mathrm{P}\right]$ ATP (NEN Life Science Products), and the mixtures were incubated for $30 \mathrm{~min}$ at $37^{\circ} \mathrm{C}$. The reactions were terminated by the addition of SDS sample buffer and boiling. Phosphorylation of the proteins was detected by autoradiography and quantified by using Image Analyzer BAS5000 (Fuji Film, Tokyo, Japan). The amounts of precipitated proteins were confirmed by probing the blots with specific antibodies.

Cytokine assays. $\mathrm{CD}^{+} \mathrm{T}$ cells $\left(3 \times 10^{5}\right)$ were cultured for $48 \mathrm{~h}$ (for IL-2) or $36 \mathrm{~h}$ (for IL-10) on plates coated with an anti-TCR MAb. An anti-IL-2 receptor $\alpha$-chain MAb (3C7) was added to the culture for the IL-2 assay to inhibit the consumption of IL-2 (24). The levels of cytokines in the supernatants were determined by a sandwich enzyme-linked immunosorbent assay (ELISA). IL-2 was measured by using MAb JES6-1A12 as the capture antibody and biotinylated MAb JES6-5H4 as the detecting antibody according to the manufacturer's directions (all MAbs for the ELISA were from BD Biosciences PharMingen). IL-10 was measured by using MAb JES5-2A5 and biotinylated MAb SXC-1.

RT-PCR. Total cellular RNA was extracted by the acid-guanidium thiocyanate-phenol-chloroform method with Isogen (Nippon-Gene, Tokyo, Japan). RNA $(1 \mu \mathrm{g})$ was reverse transcribed by using Moloney murine leukemia virus reverse transcriptase (RT) (Sawaday Technology, Tokyo, Japan). Aliquots of the mixture $(0.1 \mu \mathrm{g}$ of cDNA) then were amplified by using Taq DNA polymerase (Promega, Mannheim, Germany).

The following primer pairs were used for the PCR: IL-2 forward, $5^{\prime}$-AACA GCGCACCCACTTCAA-3'; IL-2 reverse, 5'-TTGAGATGATGCTTTGACA3'; IL-10 forward, 5'-TCAAACAAAGGACCAGCTGGACAACATACTG-3'; IL-10 reverse, TAB1 forward, 5'-GCTGGACAGATGACCTGCCTCTCTGCC3'; TAB1 reverse, 5'-CTCCTGGTTGGCCTGCCCAGGCCCAT-3'; GATA3 forward, 5'-AGAACCGGCCCCTTATCAA-3'; GATA3 reverse, 5'-AGTTCGC GCAGGATGTCC-3'; T-bet forward, 5'-CAACAACCCCTTTGCCAAAG-3'; T-bet reverse, 5'-TCCCCCAAGCAGTTGACAGT-3'; G3PDH forward, 5'-AC CACAGTCCATGCCATCAC-3'; and G3PDH reverse, 5'-TCCACCACCCTG TGCTGTA-3'.

Samples were amplified for 25 cycles with the IL-2, T-bet, GATA3, and G3PDH probes $\left(94^{\circ} \mathrm{C}\right.$ for $60 \mathrm{~s}, 58^{\circ} \mathrm{C}$ for $60 \mathrm{~s}$, and $72^{\circ} \mathrm{C}$ for $\left.60 \mathrm{~s}\right)$; for 36 cycles with the IL-10 probe $\left(94^{\circ} \mathrm{C}\right.$ for $30 \mathrm{~s}, 56^{\circ} \mathrm{C}$ for $50 \mathrm{~s}$, and $72^{\circ} \mathrm{C}$ for $\left.90 \mathrm{~s}\right)$; and for 18,24 , 30 , and 36 cycles with the TAB1 probe $\left(94^{\circ} \mathrm{C}\right.$ for $30 \mathrm{~s}, 53^{\circ} \mathrm{C}$ for $50 \mathrm{~s}$, and $72^{\circ} \mathrm{C}$ for $90 \mathrm{~s})$. The PCR products were separated by using $2 \%$ agarose gels and visualized by staining with ethidium bromide.

Retroviral transduction. The cDNA encoding human TAB1 (a gift from $\mathrm{K}$. Matsumoto, Nagoya University) (34) was subcloned into retroviral vector pMSCVneo (BD Biosciences Clontech, Palo Alto, Calif.). Packaging cell line PT67 was transfected with vector pMSCVneo alone (mock) or with pMSCVneo containing full-length TAB1 cDNA by using DMRIE-C reagent (Invitrogen, Carlsbad, Calif.), and the supernatant was harvested after $36 \mathrm{~h}$ of culturing. T-cell hybridoma 2B4 (31) was infected with the retrovirus-containing supernatant in the presence of Polybrene $(8 \mu \mathrm{g} / \mathrm{ml})$ for 60 to $72 \mathrm{~h}$. The resulting cell line (TAB1-2B4) was cultured in the presence of G418 $(500 \mu \mathrm{g} / \mathrm{ml})$ to obtain stably transduced cell lines. cDNAs encoding mouse wild-type p38 and dominantnegative p38 (p38DN) were kindly provided by Roger J. Davis (University of Massachusetts) (29) and were subcloned into retroviral vector pMSCVpuro (BD Biosciences Clontech). Supernatant was collected from cell line PT67 transfected with the resulting plasmids and used to produce Mock-2B4 (vector alone) and p38DN-2B4 cell lines. The cell lines were cultured in the presence of G418 (500 $\mu \mathrm{g} / \mathrm{ml})$ and puromycin $(1 \mu \mathrm{g} / \mathrm{ml})$ to obtain stably transduced cell lines.

Reporter gene assay. A luciferase reporter plasmid containing the mouse IL-10 promoter $(-1536$ to +64$)$ was a kind gift from S. Smale (University of California at Los Angeles) (7). The reporter gene assay was performed by using a dual luciferase reporter assay system (Promega). Jurkat cells $\left(10^{7}\right)$ were transiently transfected with vector pCMVF, which contained no insert or human TAB1 cDNA $(10 \mu \mathrm{g})$, in addition to internal control phRL-TK $(3 \mu \mathrm{g})$ and luciferase reporter construct pGL2B driven by the mouse IL-10 promoter $(-1536$ to +64$)(5 \mu \mathrm{g})$ by electroporation $(220 \mathrm{~V}, 65 \mathrm{~ms})$ with a Gene Pulser (Bio-Rad, Hercules, Calif.). After $24 \mathrm{~h}$ of culturing, cells were treated with phorbol myristate acetate (PMA) $(100 \mathrm{ng} / \mathrm{ml})$ and ionomycin $(2 \mu \mathrm{M})$ for $18 \mathrm{~h}$, and cell lysates were analyzed for luciferase activity according to the manufacturer's instructions (Promega).

\section{RESULTS}

Activation of p38 MAPK in anergic T cells. T-cell anergy was induced in the majority of $\mathrm{T}$ cells in VB8.1-tg mice after inoculation of T-cell-depleted CBA/J (Mls-1 $\left.{ }^{\mathrm{a}}\right)$ spleen cells. Both 
A

\section{p38}

Naive Anergic

$\begin{array}{lllllllll}0 & 5 & 15306090 & 0 & 5 & 15 & 306090 & \mathrm{~min}\end{array}$

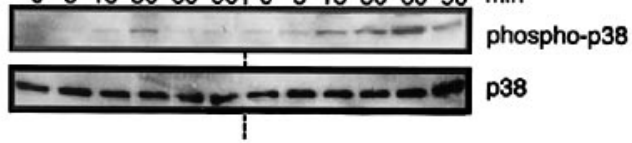

ERK

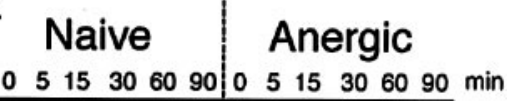

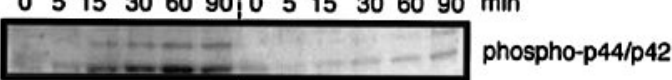

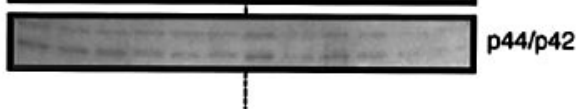

JNK

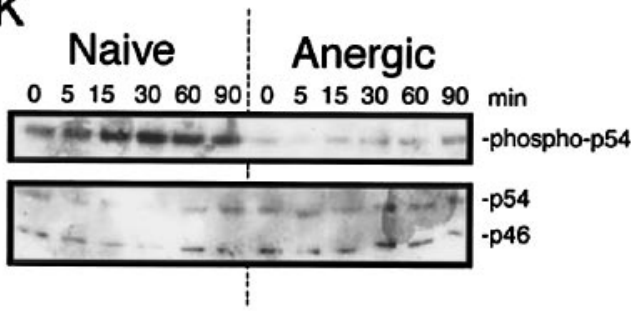

B

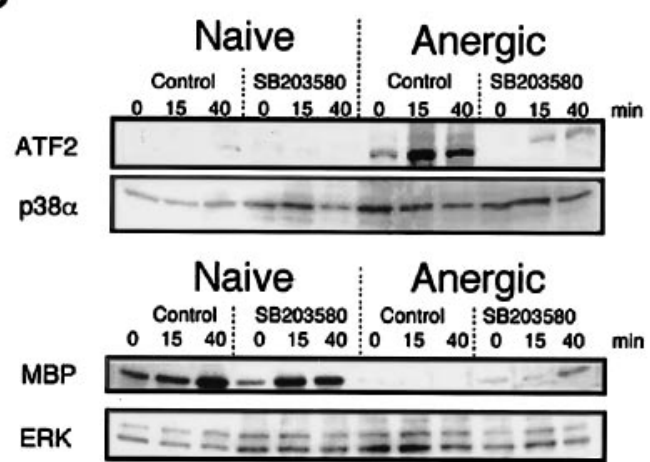

FIG. 1. Anergic $\mathrm{CD} 4^{+} \mathrm{T}$ cells show decreased activation of ERK and JNK and increased activation of p38 MAPK in response to TCR stimulation. (A) $\mathrm{CD}^{+}{ }^{+} \mathrm{T}$ cells were purified from untreated $\mathrm{V} \beta 8.1$-tg mice (naive) or Mls- $1^{\mathrm{a}}$-treated V $\beta 8.1$-tg mice (anergic) by treatment of lymph node cells with anti-CD8 MAb and complement, followed by nylon wool column enrichment. Cells were cultured for $3 \mathrm{~h}$ at $37^{\circ} \mathrm{C}$ in complete medium to decrease basal levels of MAPK activity. Cells then were placed in anti-TCR MAb $(10 \mu \mathrm{g} / \mathrm{ml})$-coated plates for various times and lysed, and the levels of phosphorylated and total MAPKs were determined by immunoblotting with specific antibodies. Representative results from three independent experiments are shown. (B) In vitro immune complex kinase assay of p38 $\alpha$ and ERK1. Naive or anergic $\mathrm{CD} 4^{+} \mathrm{T}$ cells were prepared as described for panel A and placed in anti-TCR MAb $(10 \mu \mathrm{g} / \mathrm{ml})$-coated plates in the presence or absence of SB203580 for various times. Cell lysates were immunoprecipitated with anti-p38 $\alpha$ or anti-ERK1 antibody, and in vitro kinase assays of the immunoprecipitates were performed with ATF2 and maltose-binding protein (MBP) as substrates for p38 $\alpha$ and ERK1, respectively. Proteins were separated by SDS-PAGE and analyzed by autoradiography. The quantities of p38 $\alpha$ and ERK1 were assessed by probing the immunoblots with antibodies specific for $\mathrm{p} 38 \alpha$ or ERK1. Representative results from three independent experiments are shown.
A
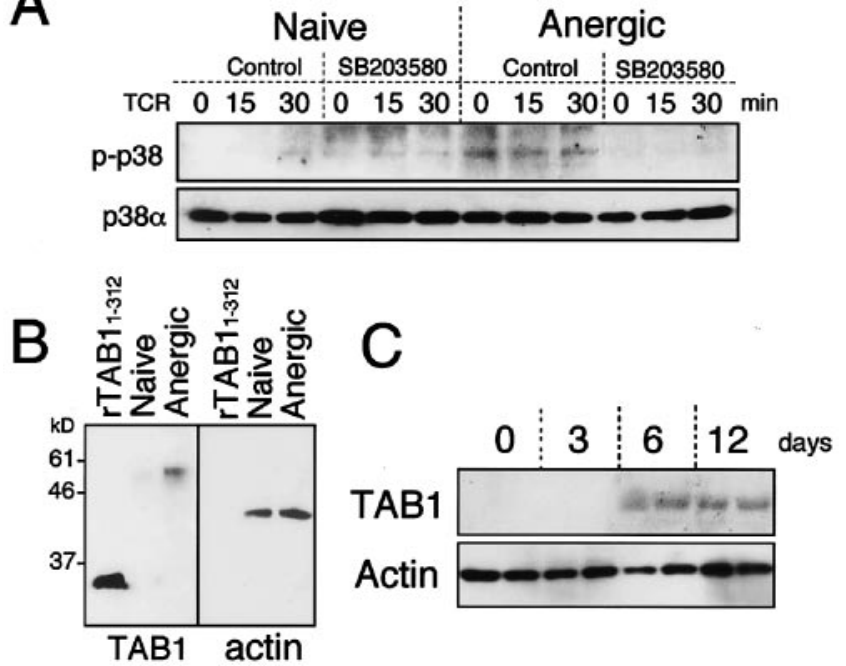

D

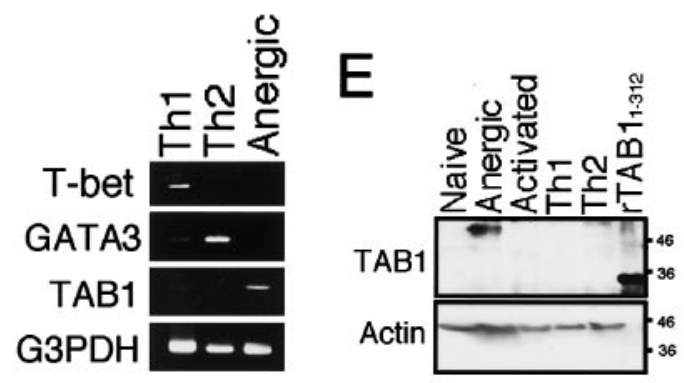

FIG. 2. Anergic $\mathrm{CD} 4^{+} \mathrm{T}$ cells express TAB1. (A) Naive and anergic $\mathrm{CD} 4^{+} \mathrm{T}$ cells were purified by using $\mathrm{BD}$ IMag-anti-mouse CD4 $\mathrm{MAb}$, cultured with or without SB203580 $(10 \mu \mathrm{M})$ for $2 \mathrm{~h}$ before stimulation, and plated in wells coated with anti-TCR MAb $(10 \mu \mathrm{g} / \mathrm{ml})$ for 0,15 , or $30 \mathrm{~min}$. Cells were harvested and lysed, and the levels of phospho-p38 and total p38 $\alpha$ were determined by immunoblotting with specific antibodies. Representative results from three independent experiments are shown. (B) Lysates from naive and anergic $\mathrm{CD} 4^{+} \mathrm{T}$ cells $\left(4 \times 10^{6} /\right.$ lane $)$ were separated by SDS- $12.5 \%$ PAGE and examined for the presence of TAB1 by immunoblotting with specific antibodies. After stripping, the membrane was immunoblotted with antiactin antibody. rTAB1 $1_{1-312}$, N-terminal 312-amino-acid fragment of recombinant TAB1. (C) Expression of TAB1 during the induction of T-cell anergy. $\mathrm{CD} 4{ }^{+} \mathrm{T}$ cells were purified from individual mice on the indicated days after Mls- $1^{\text {a }}$ inoculation. Lysates from two samples per group were separated by SDS-12.5\% PAGE and examined for the expression of TAB1 by immunoblotting. Representative results from two independent experiments are shown. (D) $\mathrm{CD}^{+} \mathrm{T}$ cells from OT-II mice were cultured for 7 days in Th1 and Th 2 mixtures. Anergic CD $4^{+}$ $\mathrm{T}$ cells were prepared from V 38.1 -tg mice 14 days after Mls- $1^{\mathrm{a}}$ inoculation (anergic), RNA was extracted from each cell type, and RTPCR analysis of T-bet, GATA3, TAB1, and G3PDH was performed as described in Materials and Methods. (E) $\mathrm{CD}^{+} \mathrm{T}$ cells were prepared from VB8.1-tg mice (naive). Anergic, Th1, and Th2 cells were prepared as described for panel D. CD4 ${ }^{+} \mathrm{T}$ cells from V $\beta 8.1$-tg mice were stimulated with anti-TCR MAb $(0.5 \mu \mathrm{g} / \mathrm{ml})$ and soluble anti-CD28 MAb $(1 \mu \mathrm{g} / \mathrm{ml})$ for $24 \mathrm{~h}$ in vitro (activated). Total cell lysates were separated by SDS-12.5\% PAGE, blotted, and probed with anti-TAB1 antibody. A recombinant TAB1 fragment $\left(\mathrm{rTAB}_{1-312}\right)$ was used as a positive control.

proliferation and IL-2 production in response to Mls- $1^{\mathrm{a}}$ or anti-TCR MAb were impaired in $\mathrm{CD}^{+}{ }^{+} \mathrm{T}$ cells from Mls- ${ }^{\mathrm{a}}{ }_{-}$

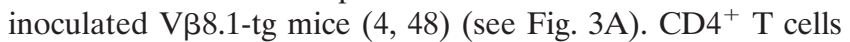
from naive V $\beta 8.1$-tg mice (naive $\mathrm{CD}^{+}{ }^{+} \mathrm{T}$ cells) and from mice 

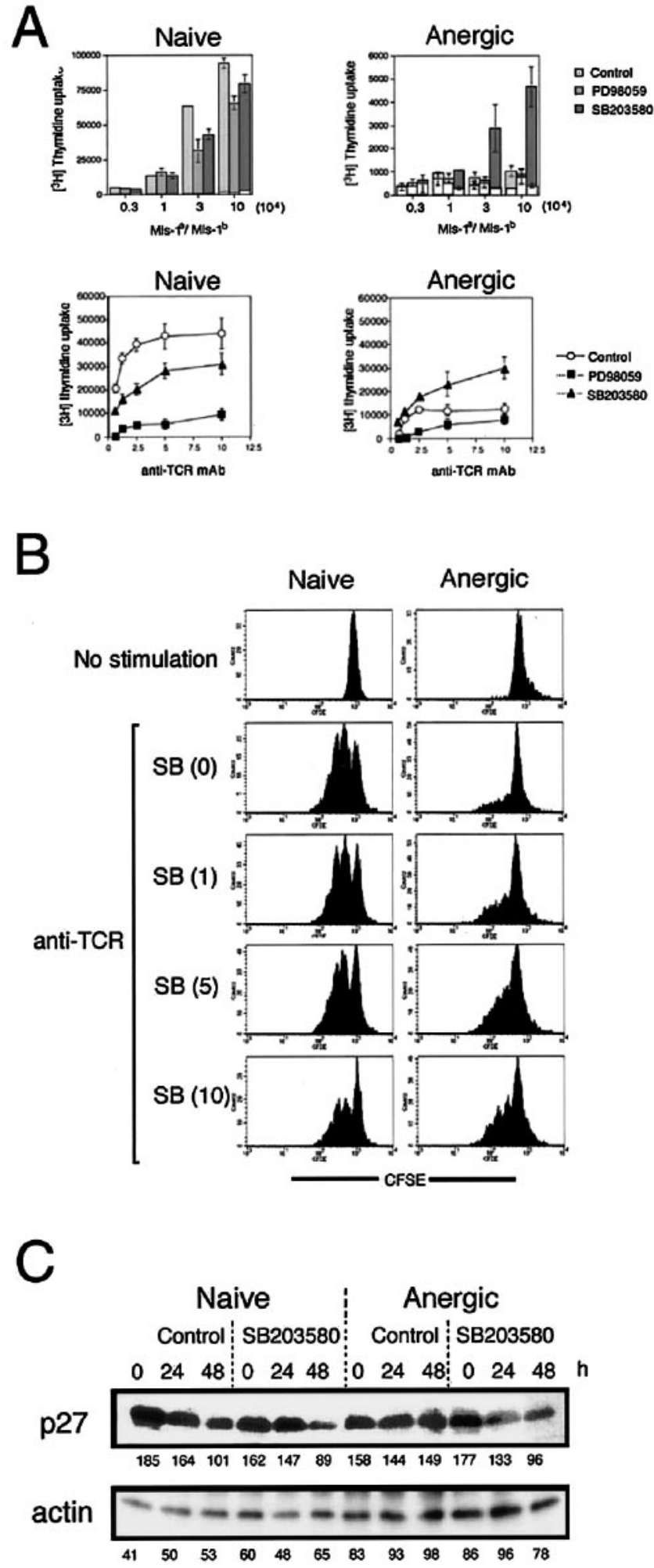

FIG. 3. T-cell proliferation is inhibited by p38 MAPK activity in anergic $\mathrm{CD}^{+} \mathrm{T}$ cells. (A) Naive and anergic $\mathrm{CD} 4^{+} \mathrm{T}$ cells were pretreated with dimethyl sulfoxide (control), PD98059 $(10 \mu \mathrm{M})$, or SB203580 $(10 \mu \mathrm{M})$ for $2 \mathrm{~h}$ and were cocultured with mitomycin Ctreated T-cell-depleted $\mathrm{CBA} / \mathrm{J}\left(\mathrm{Mls}-1^{\mathrm{a}}\right)$ or $\mathrm{CBA} / \mathrm{Ca}\left(\mathrm{Mls}-1^{\mathrm{b}}\right)$ spleen cells in the presence or absence of a lower concentration $(2 \mu \mathrm{M})$ of the inhibitors (top) or stimulated with anti-TCR MAb (0.625 to $10 \mu \mathrm{g} / \mathrm{ml})$ in the same manner (bottom). Cultures were maintained for 3 days, that were injected with T-cell-depleted CBA/J spleen cells (anergic $\mathrm{CD}^{+}{ }^{+} \mathrm{T}$ cells) expressed comparable levels of TCR and CD4 $(4,48)$. The proportions of CD25 ${ }^{+}$cells in the naive and anergic $\mathrm{CD}^{+}-\mathrm{T}$-cell populations were $\sim 6 \%$ and $\sim 13 \%$, and those of $\mathrm{CD} 44^{\text {low }} \mathrm{CD} 45 \mathrm{RB}^{\text {high }}$ cells were $\sim 82 \%$ and $\sim 35 \%$, respectively.

To determine the activities of MAPKs, naive and anergic $\mathrm{CD}^{+} \mathrm{T}$ cells were cultured for $3 \mathrm{~h}$ to decrease the basal level of MAPK activation and were stimulated with plate-bound anti-TCR MAb. The activation status of MAPKs in these T cells was evaluated by immunoblotting with phospho-specific antibodies (Fig. 1A). Phosphorylation of p38 after TCR stimulation was enhanced in anergic $\mathrm{CD}^{+} \mathrm{T}$ cells over that in naive $\mathrm{CD}^{+} \mathrm{T}$ cells, which showed limited phosphorylation. In contrast, the phosphorylation of ERK and JNK in anergic $\mathrm{CD}^{+}{ }^{+} \mathrm{T}$ cells was severely reduced, consistent with the previous report of $\mathrm{T}$ cells that were anergized in vitro $(10,19)$ or in vivo (25).

Next, we evaluated the activity of $\mathrm{p} 38 \alpha$ and ERK by using an in vitro kinase assay (Fig. 1B). The kinase activity of $\mathrm{p} 38 \alpha$ in anergic $\mathrm{CD}^{+}{ }^{+} \mathrm{T}$ cells was detectable after $3 \mathrm{~h}$ in resting cultures and was enhanced by stimulation with anti-TCR MAb. In contrast, the activity of ERK was hardly detectable in anergic $\mathrm{CD} 4^{+} \mathrm{T}$ cells but was apparent in naive $\mathrm{CD} 4^{+} \mathrm{T}$ cells. These results indicated the marked shift in the activation status of MAPKs between naive and anergic $\mathrm{CD} 4^{+} \mathrm{T}$ cells.

TAB1 expression and TAB1-mediated phosphorylation of p38 $\boldsymbol{\alpha}$. The enhanced activation of p38 $\alpha$ in anergic CD $4^{+} \mathrm{T}$ cells suggested to us that the expression of the signaling molecule upstream of $\mathrm{p} 38 \alpha$ might be altered. There are at least two separate mechanisms that can activate p38 $\alpha$. One is dependent on a prototypical kinase cascade in which $\mathrm{p} 38 \alpha$ is phosphorylated by MKK3/6; the other is dependent on TAB1mediated p38 $\alpha$ phosphorylation (13). One way to distinguish between them is to examine the sensitivity of their own phosphorylation to an inhibitor of $\mathrm{p} 38 \alpha$ and $\beta$, SB203580. The former pathway is typically insensitive to SB203580 treatment, while the latter is sensitive (13). Therefore, we examined whether the phosphorylation of $\mathrm{p} 38$ in anergic $\mathrm{CD} 4^{+} \mathrm{T}$ cells is inhibited by SB203580 by immunoblotting (Fig. 2). SB203580 inhibited the level of phospho-p38 in anergic but not in naive $\mathrm{CD}^{+} \mathrm{T}$ cells, suggesting that the phosphorylation of $\mathrm{p} 38$ in anergic $\mathrm{T}$ cells was dependent on its own activation. Therefore,

and proliferation was assessed by measuring $\left[{ }^{3} \mathrm{H}\right]$ thymidine uptake The responses of T cells to Mls- $1^{\mathrm{a}}(\mathrm{CBA} / \mathrm{J})$ and to Mls- $1^{\mathrm{b}}(\mathrm{CBA} / \mathrm{Ca})$ are represented by shaded and open columns, respectively. Representative results from 10 independent experiments are shown. Error bars indicate standard deviations. (B) Naive and anergic $\mathrm{CD} 4^{+} \mathrm{T}$ cells were labeled with CFSE, left untreated or treated with various doses of SB203580 (SB) for $2 \mathrm{~h}$, and cultured in the presence of one-fifth the indicated concentrations of SB203580 for 3 days in wells of anti-TCR MAb-coated plates. Cells then were stained with phycoerythrin-anti$\mathrm{CD} 4 \mathrm{MAb}$ and analyzed by flow cytometry. Representative results from three independent experiments are shown. (C) Naive and anergic $\mathrm{CD}^{+}{ }^{+} \mathrm{T}$ cells were stimulated with anti-TCR MAb $(10 \mu \mathrm{g} / \mathrm{ml})$ for the indicated times in the presence or absence of SB203580, and the expression of $\mathrm{p} 27 / \mathrm{kip} 1$ was analyzed by Western blotting. The expression of actin was used as a control. Arbitrary densitometric units for these bands were analyzed by using NIH Image software. Representative results from three independent experiments are shown. 
A
IL-2
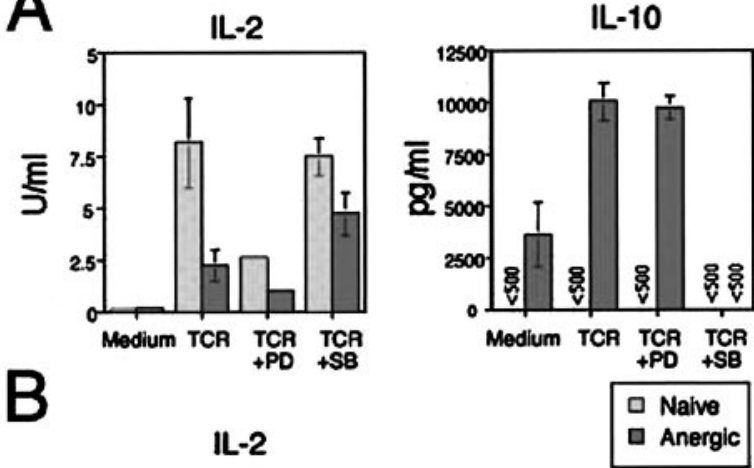

C
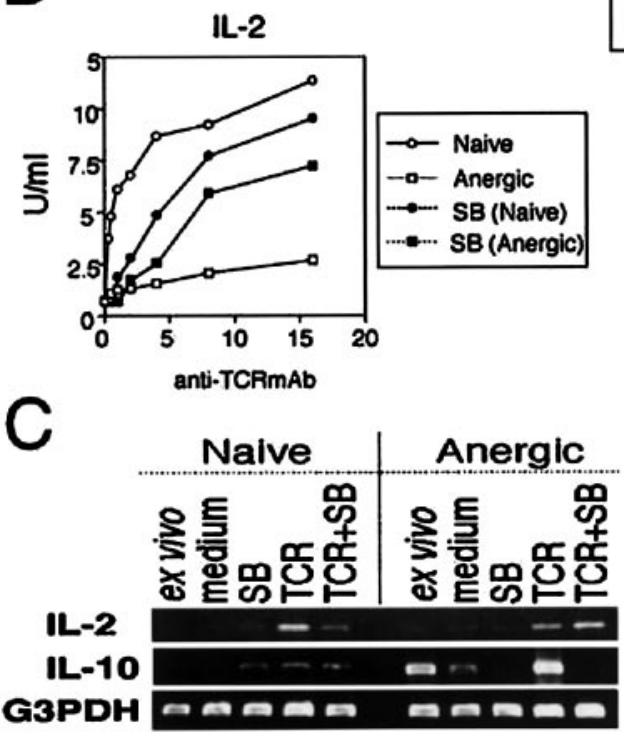

FIG. 4. The production of IL-2 is inhibited by p38 activity in anergic $\mathrm{CD} 4^{+} \mathrm{T}$ cells, while IL-10 production is $\mathrm{p} 38$ dependent. (A) $\mathrm{CD} 4^{+}$ $\mathrm{T}$ cells from untreated (naive) or CBA/J-inoculated (anergic) V $\beta 8.1$-tg mice were cultured in plates coated with anti-TCR MAb in the presence or absence of SB203580 (SB) or PD98059 (PD). Culture supernatants were collected $48 \mathrm{~h}$ (for IL-2) or $36 \mathrm{~h}$ (for IL-10) later, and the levels of IL-2 and IL-10 were determined by an ELISA. An anti-IL-2 receptor $\alpha$-chain MAb (3C7) was added to the culture for the IL-2 assay to inhibit the consumption of IL-2. Representative results from three independent experiments are shown. Error bars indicate standard deviations. (B) Naive and anergic $\mathrm{CD} 4^{+} \mathrm{T}$ cells were cultured in plates coated with various doses of anti-TCR MAb in the presence or absence of SB203580, and the levels of IL-2 in supernatants were determined as described for panel A. Representative results from three independent experiments are shown. (C) Expression of mRNAs for IL-2, IL-10, and G3PDH in naive or anergic CD4 ${ }^{+} \mathrm{T}$ cells. Naive or anergic $\mathrm{CD}^{+}{ }^{+} \mathrm{T}$ cells were plated on anti-TCR MAb $(10 \mu \mathrm{g} / \mathrm{ml})$ coated plates in the presence or absence of SB203580 as described in the legend to Fig. $1 \mathrm{~A}$ for $18 \mathrm{~h}$, and total RNA was purified from each well. cDNA samples $(0.1 \mu \mathrm{g})$ from RNA were amplified for 25 cycles for IL-2 and G3PDH or for 36 cycles for IL-10 by RT-PCR. Representative results from three independent experiments are shown.

we examined whether TAB1 is expressed in these $\mathrm{CD}^{+} \mathrm{T}$ cells by RT-PCR (data not shown) and immunoblotting (Fig. 2B). Anergic $\mathrm{CD}^{+}{ }^{+} \mathrm{T}$ cells showed clear expression of TAB1, in contrast to little expression in naive $\mathrm{CD}^{+}{ }^{+} \mathrm{T}$ cells. Thus, we concluded that naive $\mathrm{CD} 4^{+} \mathrm{T}$ cells do not express significant levels of TAB1. The study of expression kinetics indicated that the expression of TAB1 in $\mathrm{CD} 4^{+} \mathrm{T}$ cells became detectable 6 days after superantigen inoculation, corresponding to the induction of T-cell anergy (Fig. 2C).

We also examined the expression of TAB1 in $\mathrm{T}$ cells that were activated in vitro or that were cultured with Th1 and Th2 mixtures (Fig. 2D and E). CD4 ${ }^{+} \mathrm{T}$ cells cultured with Th1 and Th2 mixtures preferentially expressed T-bet and GATA3, respectively, transcription factors regulating Th1 and Th2 differentiation. The expression of TAB1 was, however, barely detectable by RT-PCR and Western blot analysis. Also, CD $4^{+} \mathrm{T}$ cells activated by stimulation with anti-TCR MAb plus antiCD28 MAb for $24 \mathrm{~h}$ did not express TAB1. These results indicated that TAB1 is specifically expressed in anergic $\mathrm{CD}^{+}$ $\mathrm{T}$ cells and can induce the phosphorylation of $\mathrm{p} 38 \alpha$.

Effect of MAPK inhibitors on anergic $\mathbf{T}$ cells. To investigate the role of the activated p38 pathway in the maintenance of anergy, we examined whether SB203580 can modulate the anergic state of $\mathrm{CD}^{+} \mathrm{T}$ cells. Treatment of anergic $\mathrm{T}$ cells with SB203580 inhibited the activity of p38 but also slightly increased ERK activity (Fig. 1B). The proliferative responses of naive and anergic $\mathrm{CD}^{+} \mathrm{T}$ cells were evaluated in the presence of MEK1 inhibitor PD98059 or SB203580. These cells were pretreated with PD98059 $(10 \mu \mathrm{M})$ or SB203580 (10 $\mu \mathrm{M})$ for $2 \mathrm{~h}$ and were stimulated with Mls- ${ }^{\mathrm{a}}$ or plate-bound anti-TCR MAb in the presence of a lower concentration of the inhibitors $(2 \mu \mathrm{M})$. Both inhibitors suppressed the proliferative responses of naive $\mathrm{CD} 4^{+} \mathrm{T}$ cells to TCR occupancy. However, SB203580 augmented the proliferative responses of anergic $\mathrm{CD}^{+} \mathrm{T}$ cells in response to Mls- $1^{\mathrm{a}}$ and anti-TCR MAb (Fig. $3 \mathrm{~A}$ and $\mathrm{B})$. We obtained similar results with another p38 kinase inhibitor, FR167653 (32) (data not shown).

To monitor the responses of $\mathrm{CD}^{+}{ }^{+} \mathrm{T}$ cells at the population level, we labeled the cells with fluorescent dye CFSE and examined their proliferation by measuring the diminution of the CFSE level (Fig. 3B) (20). Proliferation of anergic CD4 ${ }^{+} \mathrm{T}$ cells in response to anti-TCR MAb was augmented by SB203580 in a dose-dependent manner. We also examined the level of a p27/kip1 cyclin-dependent kinase inhibitor which was reported to regulate the blockade of the cell cycle in anergic $\mathrm{CD}^{+} \mathrm{T}$ cells (6). The level of $\mathrm{p} 27 / \mathrm{kip} 1$ was reduced $48 \mathrm{~h}$ after stimulation of naive but not anergic $\mathrm{CD}^{+}{ }^{+} \mathrm{T}$ cells. In the presence of SB203580, however, the expression of p27/kip1 was reduced $48 \mathrm{~h}$ after TCR stimulation in anergic $\mathrm{CD}^{+}{ }^{+} \mathrm{T}$ cells (Fig. 3C), suggesting that the cells produced IL-2 and thus induced the degradation of p27/kip1 (Fig. 4).

Cytokine production by anergic $\mathrm{CD}^{+} \mathrm{T}$ cells. We next examined the production of cytokines in the presence of MAPK inhibitors (Fig. 4). PD98059 inhibited the production of IL-2 in response to anti-TCR MAb in both naive and anergic $\mathrm{CD}^{+}{ }^{+} \mathrm{T}$ cells. SB203580 partially inhibited the production of IL-2 by naive $\mathrm{CD}^{+} \mathrm{T}$ cells but also enhanced IL-2 production by anergic $\mathrm{CD}^{+} \mathrm{T}$ cells (Fig. 4A). We also evaluated the production of IL-10, since in vivo-anergized $\mathrm{CD}^{+}{ }^{+} \mathrm{T}$ cells could produce IL-10 $(8,23,37)$. Although naive $\mathrm{CD}^{+}{ }^{+} \mathrm{T}$ cells produced barely detectable levels of IL-10 in our assay, anergic $\mathrm{CD}^{+}{ }^{+} \mathrm{T}$ cells secreted IL-10 without stimulation and produced higher levels of IL-10 after culturing with anti-TCR MAb. SB203580 completely inhibited the production of IL-10 by anergic $\mathrm{CD}^{+} \mathrm{T}$ cells, indicating that the production of IL-10 by anergic $\mathrm{CD}^{+} \mathrm{T}$ cells is p38 dependent. To determine whether the level of cytokine production was regulated at the 

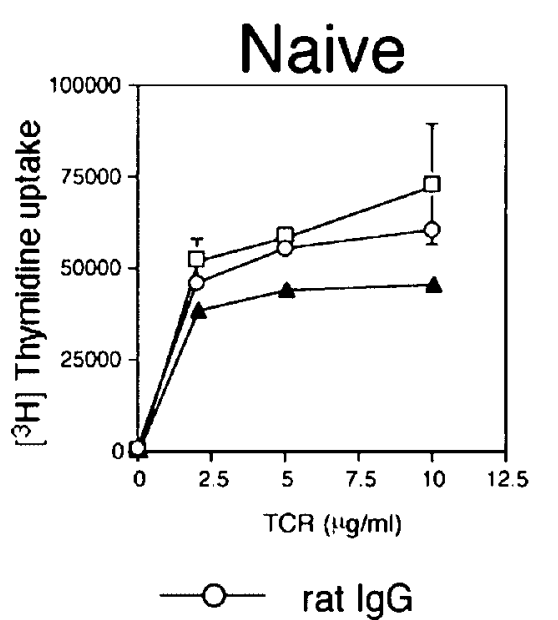

............. SB203580+rat lgG

$\cdots$ anti-IL-10 mAb

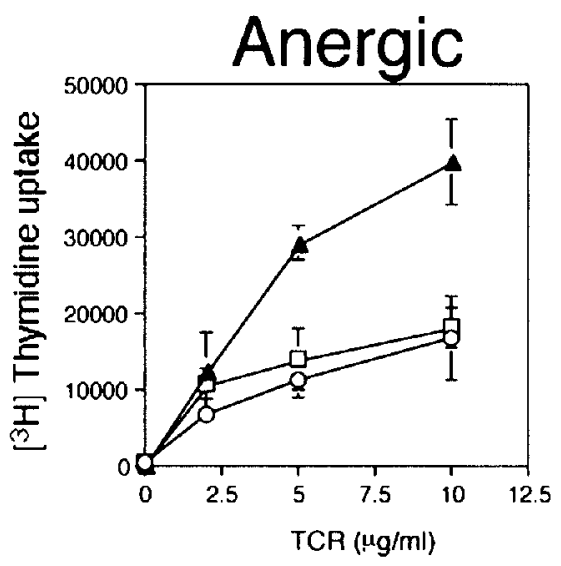

FIG. 5. The maintenance of unresponsiveness in anergic $\mathrm{CD} 4^{+} \mathrm{T}$ cells is independent of IL-10 production. Naive and anergic $\mathrm{CD} 4^{+} \mathrm{T}$ cells were cultured in plates coated with anti-TCR MAb $(0$ to $10 \mu \mathrm{g} / \mathrm{ml})$. The cultures were maintained in the presence of control rat immunoglobulin $\mathrm{G}(\mathrm{IgG} ; 20 \mu \mathrm{g} / \mathrm{ml})$, anti-IL-10 MAb $(20 \mu \mathrm{g} / \mathrm{ml})$, or SB203580 $(2 \mu \mathrm{M})$ plus control rat IgG for $72 \mathrm{~h}$, and proliferation was assessed by measuring the incorporation of $\left[{ }^{3} \mathrm{H}\right]$ thymidine. Cells cultured in the presence of SB203580 were incubated with the inhibitor at a final concentration of 10 $\mu \mathrm{M}$ for $2 \mathrm{~h}$ before TCR stimulation. Representative results from three independent experiments are shown. Error bars indicate standard deviations.

level of mRNA expression, RT-PCR analysis of IL-2 and IL-10 was performed (Fig. 4C). Anergic $\mathrm{CD}^{+}{ }^{+} \mathrm{T}$ cells expressed a high level of IL-10 mRNA ex vivo and maintained this high level upon stimulation in vitro with anti-TCR MAb. The expression of IL-10 mRNA by anergic $\mathrm{CD}^{+}{ }^{+} \mathrm{T}$ cells was clearly inhibited by SB203580.

One possible explanation for the increased proliferation and IL-2 production of anergic CD4 ${ }^{+} \mathrm{T}$ cells in the presence of SB203580 was a reduction in IL-10 production, which might otherwise have suppressed the response of these cells. To exclude this possibility, we attempted to determine whether the addition of neutralizing anti-IL-10 MAb could induce the proliferation of anergic CD4 ${ }^{+} \mathrm{T}$ cells (Fig. 5). Anti-IL-10 MAb $(20 \mu \mathrm{g} / \mathrm{ml})$ had little effect on the proliferative response of anergic $\mathrm{CD}^{+} \mathrm{T}$ cells. The concentration of anti-IL-10 MAb used in this assay was sufficient to neutralize the activity of IL-10, since this concentration of anti-IL-10 MAb was able to completely block the inhibitory effect of recombinant IL-10 on the costimulatory activity of anti-CD28 MAb on the CD4 ${ }^{+}-\mathrm{T}$ cell proliferative response to anti-TCR MAb (data not shown) (1). Thus, the effect of SB203580 on the proliferation of anergic $\mathrm{CD}^{+}{ }^{+} \mathrm{T}$ cells was not simply due to the inhibition of IL-10 production by these cells.

TAB1 negatively regulates T-cell activation. We next examined the effect of the forced expression of TAB1 on T-cell function. Our initial attempt to transfer DNA into anergic $\mathrm{CD}^{+}{ }^{+} \mathrm{T}$ cells by using a retrovirus was unsuccessful, since anergic $\mathrm{T}$ cells did not replicate DNA. Thus, we introduced TAB1 cDNA into T-cell hybridoma 2B4 (24), which does not express endogenous TAB1 (Fig. 6A), and generated stable cell lines containing vector alone (Mock-2B4) or TAB1 (TAB12B4). As expected, p38 $\alpha$ kinase was constitutively active and phospho-p38 was detected in TAB1-2B4 cells (Fig. 6B and C). Treatment of TAB1-2B4 cells with SB203580 resulted in downregulation of the phospho-p38 level, indicating that the phosphorylation of p38 depends on its own activity. RT-PCR of IL-2 and IL-10 mRNAs indicated that TAB1-2B4 cells expressed lower levels of IL-2 mRNA both before and after TCR stimulation compared with Mock-2B4 cells (Fig. 6D). IL-10 mRNA was detectable in TAB1-2B4 cells but not in Mock-2B4 cells. The production of IL-2 in the supernatant was reduced in TAB1-2B4 cells after stimulation with anti-TCR MAb as well as PMA and ionomycin (Fig. 6E). The IL-10 reporter assay showed that the expression of TAB1 induced IL-10 promoter activity in Jurkat cells and that this effect was augmented by stimulation with PMA and ionomycin (Fig. 6F).

The effect of TAB1 on the activation of ERK was investigated by immunoblotting (Fig. 7). We used PMA to activate ERK kinase in 2B4 cells, since the phosphorylation of ERK in 2B4 cells after stimulation with anti-TCR MAb was barely detectable. The stimulation of TAB1-2B4 cells with various doses of PMA induced phospho-ERK to levels lower than those in Mock-2B4 cells (Fig. 7A). However, these cells showed increased levels of phospho-ERK in the presence of SB203580 (Fig. 7B). To confirm that this recovery of ERK activation in the presence of SB203580 resulted from the inhibition of $\mathrm{p} 38$, we introduced $\mathrm{p} 38 \mathrm{DN}$ into Mock-2B4 or TAB1-2B4 cells and generated stable cell lines containing vector alone (Mock/Mock-2B4 and TAB1/Mock-2B4) or p38DN (Mock/p38DN-2B4 and TAB1/p38DN-2B4). In TAB1-2B4 cells, the levels of ERK protein expression were up-regulated for unknown reasons, but it was clear that PMA-induced ERK activation was up-regulated in TAB1/p38DN-2B4 cells compared with TAB1/Mock-2B4 cells. We also examined the acti- 

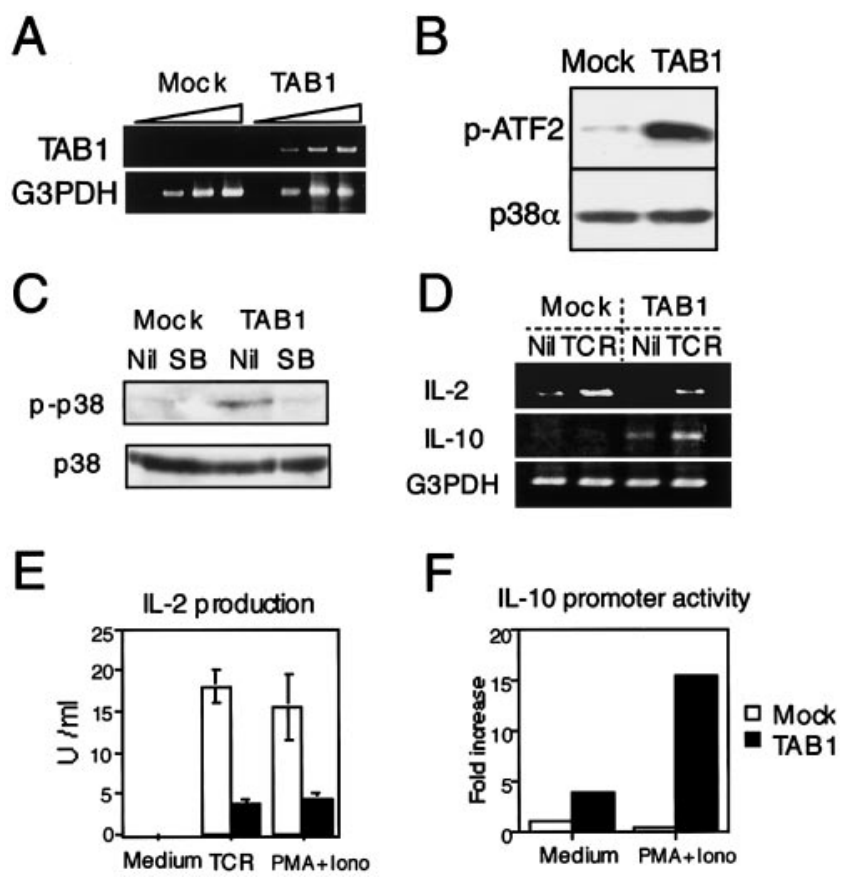

FIG. 6. TAB1 inhibits IL-2 and increases IL-10 production. (A) Tcell hybridoma $2 \mathrm{~B} 4$ was transduced with retrovirus that contained the vector alone (Mock) or human TAB1 (TAB1), and stable cell lines were selected in the presence of G418 $(500 \mu \mathrm{g} / \mathrm{ml})$. RNA was prepared from each cell line and was subjected to RT-PCR analysis for TAB1 mRNA expression. PCR was performed for $18,24,30$, and 36 cycles (as indicated by the triangles over the lanes). (B) p38 $\alpha$ was immunoprecipitated with specific antibodies from lysates of Mock-2B4 cells (Mock) or TAB1-2B4 cells (TAB1) and was subjected to an in vitro kinase assay with ATF2 ${ }_{19-96}$ peptide as a substrate. The quantity of p38 $\alpha$ was assessed by immunoblotting with anti-p38 $\alpha$ antibody. (C) Mock-2B4 cells (Mock) and TAB1-2B4 cells (TAB1) were incubated with (SB) or without (Nil) SB203580 $(10 \mu \mathrm{M})$ for $2 \mathrm{~h}$, lysed, and subjected to immunoblotting with anti-phospho-p38 and anti-p38a antibodies. (D) Mock-2B4 cells (Mock) and TAB1-2B4 cells (TAB1) were cultured for $18 \mathrm{~h}$ in plates coated (TCR) or not coated (Nil) with anti-TCR MAb $(10 \mu \mathrm{g} / \mathrm{ml})$ and were subjected to RT-PCR analysis for IL-2, IL-10, and G3PDH mRNAs. (E) Mock-2B4 cells (Mock) and TAB1-2B4 cells (TAB1) were cultured with anti-TCR MAb (TCR) or with PMA (20 ng/ml) and ionomycin (Iono; $1 \mu \mathrm{M}$ ) for $24 \mathrm{~h}$. The levels of IL-2 in the supernatants were determined by an ELISA. Error bars indicate standard deviations. (F) Jurkat cells were transiently transfected with pGL2B luciferase reporter constructs driven by the mouse IL-10 promoter $(-1536$ to +64$)$, with vector $\mathrm{pCMVF}$, which contained either no insert (Mock) or human TAB1 cDNA (TAB1), and with internal control phRL-TK. Cells were cultured with PMA $(100 \mathrm{ng} / \mathrm{ml})$ and ionomycin $(2 \mu \mathrm{M})$ for $18 \mathrm{~h}$, and luciferase activity was measured.

vation of JNK in these cells, since the activation of JNK was also impaired in anergic $\mathrm{CD} 4^{+} \mathrm{T}$ cells. The phosphorylation of JNK after PMA treatment was reduced in TAB1-2B4 cells compared with Mock-2B4 cells. However, unlike that of ERK, the phosphorylation of JNK was not up-regulated in TAB1/ p38DN-2B4 cells (Fig. 7C), suggesting that the reduction in JNK phosphorylation in TAB1-2B4 cells was independent of p38. Further study is under way to determine the molecular basis of TAB1-mediated JNK inactivation.

Parallel to the levels of ERK activation, TAB1-2B4 cells produced less IL-2 mRNA after stimulation with PMA plus ionomycin and more IL-2 mRNA in the presence of SB203580 or p38DN (Fig. 7D and E). These results indicated that the forced expression of TAB1 in T cells resulted in the constitutive activation of $\mathrm{p} 38 \alpha$ and the inhibition of ERK activation, culminating in the reduced expression of IL-2 after T-cell activation and the induction of IL-10 expression. This response pattern was similar to that of anergic $\mathrm{CD}^{+} \mathrm{T}$ cells, which showed reduced levels of IL-2 production and proliferation even in response to various doses of PMA (1 to $25 \mathrm{ng} / \mathrm{ml}$ ) and ionomycin $(2 \mu \mathrm{M})$ (data not shown). Finally, the study of TCR-stimulated IL-2 production in these hybridoma cell lines indicated that the inhibition of IL-2 production by the introduction of TAB1 was mediated by the p38 pathway (Fig. 7F).

\section{DISCUSSION}

T-cell anergy induced by superantigen is maintained primarily by intrinsic mechanisms and is independent of regulatory $\mathrm{T}$ cells $(3,23)$. In fact, Mls- $1^{\mathrm{a}}$-induced anergy could be maintained without $\mathrm{CD} 25^{+}$regulatory $\mathrm{T}$ cells (data not shown). In this study, we investigated the molecular basis of this anergy and showed that TAB1 is expressed in $\mathrm{CD}^{+}{ }^{+} \mathrm{T}$ cells anergized in vivo and is not expressed in naive or activated $\mathrm{CD}^{+}{ }^{+} \mathrm{T}$ cells implying that TAB1 is a unique functional molecule expressed in anergic T cells. TAB1 was originally identified as an activator of the MAPK kinase kinase, TAK1, that induces MAPK activation cascade in transforming growth factor $\beta$ signaling pathway (34). It is a scaffolding protein that can also bind to p $38 \alpha$ and induces its phosphorylation. This TAB1-mediated phosphorylation of $\mathrm{p} 38 \alpha$ requires its intrinsic kinase activity, and is thus inhibited by SB203580 (13). We speculate that TAB1-mediated signaling in anergic $\mathrm{CD}^{+}{ }^{+} \mathrm{T}$ cells could regulate the distal TCR signaling events, such as the activation of MAPKs, as well as the production of cytokines after TCR engagement. In fact, forced expression of TAB1 in a T-cell hybridoma induced the activation of $\mathrm{p} 38 \alpha$ MAPK prior to T-cell activation, promoted IL-10 synthesis and was inhibitory to IL-2 expression after activation with PMA and ionomycin. In anergic $\mathrm{CD}^{+}{ }^{+} \mathrm{T}$ cells and TAB1-2B 4 cells, $\mathrm{p} 38 \alpha$ MAPK is activated prior to TCR stimulation, which can be inhibited by SB203580, indicating that phosphorylation is dependent on its own kinase activity.

We propose two possibilities for the SB203580-sensitive phosphorylation of $\mathrm{p} 38$. One is that the activation of $\mathrm{p} 38 \alpha$ itself is TAB1-mediated autophosphorylation, as was proposed by Ge et al. (13). The second possibility is that TAB1 mediates feedback control of the MAPK pathway by p38 $\alpha$ (9). Further studies are under way to distinguish between these possibilities. In either cases, these studies imply that the maintenance of Mls- $1^{\mathrm{a}}$-induced T-cell anergy is regulated at the level of MAPK signaling. In fact, the production IL-2 by anergic CD4 ${ }^{+}$ $\mathrm{T}$ cells in response to various concentrations of PMA and ionomycin was reduced when compared with control (data not shown), although some of the previous studies showed that anergic $\mathrm{T}$ cells responded normally to PMA and ionomycin (33). These differences might reflect the different degrees of T-cell anergy that can be induced in vivo $(40,45)$.

Our study showed that the effect of SB203580 treatment on MAPKs signaling and cytokine secretion differed significantly between naive and anergic CD $4^{+} \mathrm{T}$ cells. In naive $\mathrm{CD} 4^{+} \mathrm{T}$ cells, SB203580 had little effect on ERK activation and slightly 


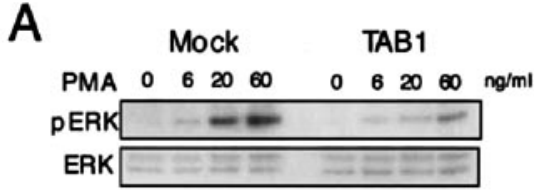

B
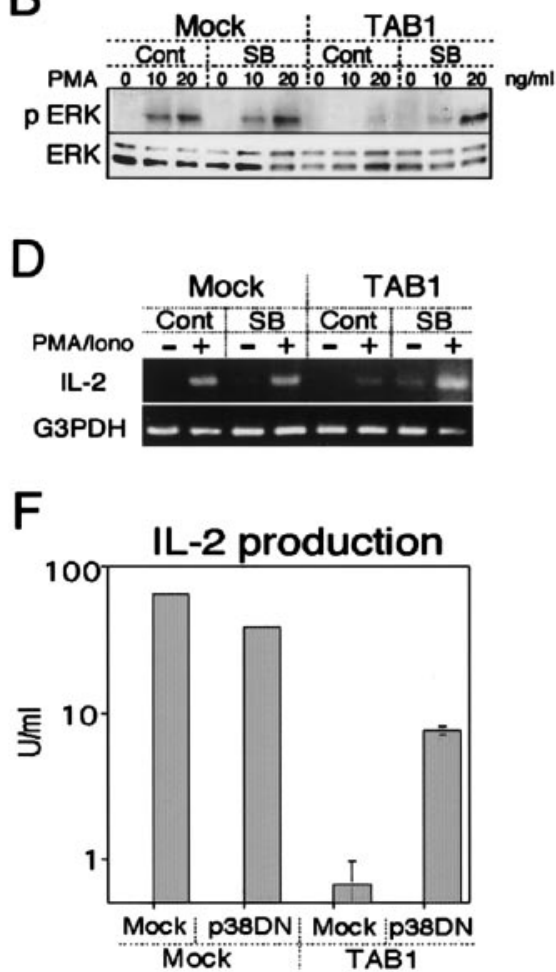
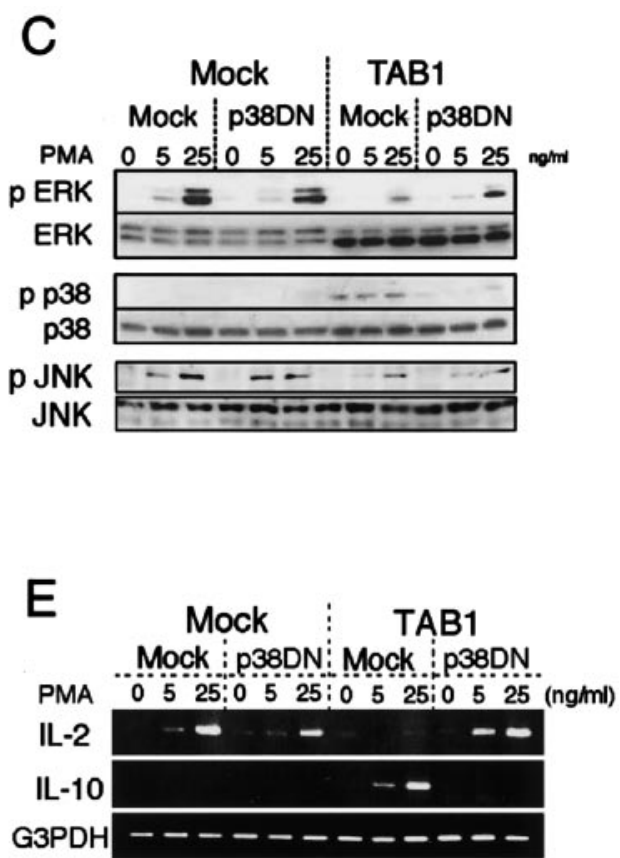

FIG. 7. The inhibition of ERK kinase activity by TAB1 is dependent on p38. (A) Mock-2B4 cells (Mock) and TAB1-2B4 cells (TAB1) were cultured with various doses of PMA (0 to $60 \mathrm{ng} / \mathrm{ml})$ for $10 \mathrm{~min}$, and the levels of phosphorylated ERK and total ERK were determined by immunoblotting with specific antibodies. (B) Mock-2B4 cells (Mock) and TAB1-2B4 cells (TAB1) were cultured in the presence (SB) or absence (Cont) of SB203580 $(10 \mu \mathrm{M})$ for $2 \mathrm{~h}$ and subsequently stimulated with PMA $(0,10$, or $20 \mathrm{ng} / \mathrm{ml})$ for 10 min. Cells were lysed, and the levels of phosphorylated ERK and total ERK were determined by immunoblotting with specific antibodies. (C) Mock-2B4 cells were transduced with a retroviral supernatant containing empty vector (Mock/Mock) or p38DN (Mock/p38DN) to establish stable cell lines. TAB1-2B4 cells were also transduced to establish cell lines expressing empty vector (TAB1/Mock) or p38DN cDNA (TAB1/p38DN). These cell lines were stimulated with PMA $(0,5$, or $25 \mathrm{ng} / \mathrm{ml})$ for $10 \mathrm{~min}$ and lysed, and the levels of phosphorylated MAPks and total MAPKs were determined by immunoblotting with specific antibodies. Representative results from two independent experiments are shown. (D) Mock-2B4 cells (Mock) and TAB1-2B4 cells (TAB1) were treated or not treated with SB203580 $(10 \mu \mathrm{M})$ for $2 \mathrm{~h}$ and stimulated with PMA $(20 \mathrm{ng} / \mathrm{ml})$ and ionomycin (Iono; $2 \mu \mathrm{M})$ for $8 \mathrm{~h}$ in the presence (SB) or absence (Cont) of SB203580, respectively. Cells were subjected to RT-PCR analysis for IL-2 and G3PDH mRNAs. Representative results from two independent experiments are shown. (E) Mock/Mock, Mock/p38DN, TAB1/Mock, and TAB1/p38DN cells were stimulated with PMA $(0,5$, or $25 \mathrm{ng} / \mathrm{ml})$ and ionomycin $(2 \mu \mathrm{M})$ for $8 \mathrm{~h}$. Cells were subjected to RT-PCR analysis for IL-2, IL-10, and G3PDH mRNAs. Representative results from two independent experiments are shown. (F) Mock/Mock, Mock/p38DN, TAB1/Mock, and TAB1/p38DN cells were stimulated with anti-TCR MAb (H57; $10 \mu \mathrm{g} / \mathrm{ml})$ for $24 \mathrm{~h}$. The levels of IL-2 in culture supernatants were determined by an ELISA. IL-2 was not detectable in cultures without anti-TCR MAb.

inhibited IL-2 production, while in anergic $\mathrm{CD}^{+}{ }^{+} \mathrm{T}$ cells, it potentiated ERK activity and IL-2 production. Although the effect of SB203580 on other molecules, such as c-Raf and MAPK kinase kinase of the ERK pathway, has been described $(16,26)$, we believe that the effect of SB203580 on anergic T cells is specific to p38. Activation of c-Raf by SB203580 cannot explain its differential effects on naive and anergic $\mathrm{CD}^{+}{ }^{+} \mathrm{T}$ cells. In addition, our study with a T-cell hybridoma indicated that the expression of TAB 1 and thus the activation of $\mathrm{p} 38 \alpha$ is critical for the effect of SB203580 on ERK activation, because SB203580 had little effect on ERK activation in Mock-2B4 cells but potentiated ERK in TAB1-2B4 cells (Fig. 6). Furthermore, the effect of SB203580 on TAB1-2B4 cells was recapitulated by the expression of p38DN. Therefore, we concluded that the activation of the ERK pathway in anergic $\mathrm{CD} 4^{+} \mathrm{T}$ cells by SB203580 was caused by the release of this pathway from the negative regulatory effects of $\mathrm{p} 38 \alpha$. Thus, the activation of $\mathrm{p} 38 \alpha$ has different effects on naive and anergic $\mathrm{CD}^{+} \mathrm{T}$ cells.

One possibility is that the constitutive activation of $\mathrm{p} 38 \alpha$ prior to TCR occupancy has a negative regulatory effect on the ERK pathway. The phosphorylation of $\mathrm{p} 38 \alpha$ in naive $\mathrm{CD}^{+} \mathrm{T}$ 
cells is mediated by MAPK kinases (MKK3 and MKK6), which are activated after TCR stimulation and thus are not inhibitory to ERK, while $\mathrm{p} 38 \alpha$ is activated prior to TCR occupancy by TAB1-mediated mechanisms in anergic $\mathrm{T}$ cells. The pretreatment of anergic $\mathrm{CD}^{+} \mathrm{T}$ cells with SB203580 may release the ERK pathway from the inhibitory effect of $\mathrm{p} 38 \alpha$. Alternatively, a third protein that associates with p38 $\alpha$ may dictate the differential outcome of $\mathrm{p} 38 \alpha$ activation in naive and anergic $\mathrm{T}$ cells. TAB1 is a 504-amino-acid protein that has a putative protein phosphatase $2 \mathrm{C}$-like domain and $\mathrm{p} 38 \alpha$ - and TAK1binding domains (14) and can form a complex with TAK1, TAB2, and TRAF6 (39). It is possible that the complex of TAB1 and $\mathrm{p} 38 \alpha$ in anergic T cells associates with a third protein, which has an inhibitory effect on the ERK pathway. Similar cross talk between two MAPK pathways has been reported in other biological systems. Singh et al. reported that p38 $\alpha$ negatively regulates the expression of a low-density lipoprotein receptor through an ERK signaling cascade in hepatoma cell line HepG2 through the use of a pharmacological inhibitor as well as constitutively active MKK6 (35). Others also showed that this type of inhibitory effect of p38 $\alpha$ on the ERK pathway could be mediated through an upstream kinase of the ERK cascades (46) or by a direct interaction between p38 and ERK (49).

$\mathrm{CD}^{+} \mathrm{T}$ cells anergized in vivo produce IL-10, a cytokine which inhibits the T-cell response and could induce anergy in peripheral $\mathrm{T}$ cells $(15,23,38)$. Repeated inoculation of superantigen SEB in vivo induced unresponsiveness of specific $T$ cells and IL-10 production (18). Influenza hemagglutinin-specific $\mathrm{T}$ cells that were rendered anergic in vivo also expressed high levels of IL-10 mRNA (8). Consistent with these studies, anergic $\mathrm{CD} 4^{+} \mathrm{T}$ cells in V $\beta 8$.1-tg mice produced IL-10. Anergic $\mathrm{CD} 4^{+} \mathrm{T}$ cells secreted IL-10 ex vivo prior to TCR stimulation and increased levels of IL-10 after TCR occupancy. The SB203580 treatment completely inhibited the production of IL-10 in anergic $\mathrm{CD}^{+} \mathrm{T}$ cells, indicating that its production depends on the activation of p38 (Fig. 3A and C). TAB1-2B4 cells also showed increased IL-10 mRNA production, similar to p38-dependent IL-10 production in human T cells $(18,27)$ and monocytes (12). However, the effect of the p38 inhibitor on the proliferation of anergic $\mathrm{CD} 4^{+} \mathrm{T}$ cells was independent of their IL-10 secretion, because neutralization of IL-10 by anti-IL-10 MAb in vitro did not rescue the proliferation of anergic $\mathrm{CD}^{+} \mathrm{T}$ cells (Fig. 4). This is consistent with the previous study, showing that a treatment of mice with neutralizing anti-IL-10 MAb prior to the challenge with superantigen did not rescue IL-2 production (37).

$\mathrm{T}$-cell unresponsiveness induced by superantigen inoculation in vivo is maintained both by the autonomous anergy of cells and by cytokine-mediated suppression $(3,23)$. The expression of TAB1 and thus the activation of $\mathrm{p} 38 \alpha$ regulate the secretion of IL-2 and IL-10 in distinct ways; one is the inhibition of ERK activation culminating in the inhibition of IL-2 production, and the other is the promotion of IL-10 production, both of which contribute to the maintenance of $\mathrm{CD} 4^{+}$ T-cell unresponsiveness. Therefore, TAB1 is a key signaling protein in the maintenance of T-cell unresponsiveness. Modulation of TAB1 activity could alter the function of anergic and regulatory $\mathrm{T}$ cells.

\section{ACKNOWLEDGMENTS}

We thank Mark I. Greene, Makoto Katsumata, and Isao Sano for help; Masakatsu Ueda for technical assistance; and Dalibor Breznan for editorial assistance with the manuscript. We are also grateful to Kunihiro Matsumoto, Roger Davis, and Stephen T. Smale for plasmids; SmithKline Beecham for SB203580; and Hajome Karasuyama for a cytokine-producing cell line.

This study was supported by grants-in-aid from the Ministry of Education, Science, Sports, and Culture in Japan and by the Nagasaki Medical Association.

\section{REFERENCES}

1. Akdis, C. A., A. Joss, M. Akdis, A. Faith, and K. Blaser. 2000. A molecular basis for T cell suppression by IL-10: CD28-associated IL-10 receptor inhibits CD28 tyrosine phosphorylation and phosphatidylinositol 3-kinase binding. FASEB J. 14:1666-1668.

2. Anandasabapathy, N., G. S. Ford, D. Bloom, C. Holness, V. Paragas, C. Seroogy, Skrenta, H., M. Hollenhorst, C. G. Fathman, and L. Soares. 2003. GRAIL: an E3 ubiquitin ligase that inhibits cytokine gene transcription is expressed in anergic CD $4^{+} \mathrm{T}$ cells. Immunity 18:535-547.

3. Attinger, A., H. Acha-Orbea, and H. R. MacDonald. 2000. Cutting edge: cell autonomous rather than environmental factors control bacterial superantigen-induced T cell anergy in vivo. J. Immunol. 165:1171-1174.

4. Bhandoola, A., E. A. Cho, K. Yui, H. U. Saragovi, M. I. Greene, and H. Quill. 1993. Reduced CD3-mediated protein tyrosine phosphorylation in anergic $\mathrm{CD}^{+}$and $\mathrm{CD}^{+}$T cells. J. Immunol. 151:2355-2367.

5. Boussiotis, V. A., G. J. Freeman, A. Berezovskaya, D. L. Barber, and L. M. Nadler. 1997. Maintenance of human T cell anergy: blocking of IL-2 gene transcription by activated Rap1. Science 278:124-128.

6. Boussiotis, V. A., G. J. Freeman, P. A. Taylor, A. Berezovskaya, I. Grass, B. R. Blazar, and L. M. Nadler. 2000. p27kip1 functions as an anergy factor inhibiting interleukin 2 transcription and clonal expansion of alloreactive human and mouse helper T lymphocytes. Nat. Med. 6:290-297.

7. Brightbill, H. D., S. E. Plevy, R. L. Modlin, and S. T. Smale. 2000. A prominent role for $\mathrm{Sp} 1$ during lipopolysaccharide-mediated induction of the IL-10 promoter in macrophages. J. Immunol. 164:1940-1951.

8. Buer, J., A. Lanoue, A. Franzke, C. Garcia, H. von Boehmer, and A. Sarukhan. 1998. Interleukin 10 secretion and impaired effector function of major histocompatibility complex class II-restricted T cells anergized in vivo. J. Exp. Med. 187:177-183.

9. Cheung, P. C., D. G. Campbell, A. R. Nebreda, and P. Cohen. 2003. Feedback control of the protein kinase TAK1 by SAPK2a/p38alpha. EMBO J. 22:5793-5805.

10. DeSilva, D. R., W. S. Feeser, E. J. Tancula, and P. A. Scherle. 1996. Anergic $\mathrm{T}$ cells are defective in both jun $\mathrm{NH}_{2}$-terminal kinase and mitogen-activated protein kinase signaling pathways. J. Exp. Med. 183:2017-2023.

11. Fields, P. E., T. F. Gajewski, and F. W. Fitch. 1996. Blocked Ras activation in anergic CD4 ${ }^{+} \mathrm{T}$ cells. Science 271:1276-1278.

12. Foey, A. D., S. L. Parry, L. M. Williams, M. Feldmann, B. M. Foxwell, and F. M. Brennan. 1998. Regulation of monocyte IL-10 synthesis by endogenous IL- 1 and TNF- $\alpha$ : role of the p38 and p42/44 mitogen-activated protein kinases. J. Immunol. 160:920-928.

13. Ge, B., H. Gram, F. Di Padova, B. Huang, L. New, R. J. Ulevitch, Y. Luo, and J. Han. 2002. MAPKK-independent activation of p38 $\alpha$ mediated by TAB1dependent autophosphorylation of p38 $\alpha$. Science 295:1291-1294.

14. Ge, B., X. Xiong, Q. Jing, J. L. Mosley, A. Filose, D. Bian, S. Huang, and J. Han. 2003. TAB1 $\beta$ (transforming growth factor- $\beta$-activated protein kinase 1-binding protein $1 \beta$ ), a novel splicing variant of TAB1 that interacts with p38 $\alpha$ but not TAK1. J. Biol. Chem. 278:2286-2293.

15. Groux, H., M. Bigler, J. E. de Vries, and M. G. Roncarolo. 1996. Interleukin-10 induces a long-term antigen-specific anergic state in human $\mathrm{CD}^{+}{ }^{+} \mathrm{T}$ cells. J. Exp. Med. 184:19-29.

16. Hall-Jackson, C. A., M. Goedert, P. Hedge, and P. Cohen. 1999. Effect of SB 203580 on the activity of c-Raf in vitro and in vivo. Oncogene 18:2047-2054.

17. Kang, S. M., B. Beverly, A. C. Tran, K. Brorson, R. H. Schwartz, and M. J. Lenardo. 1992. Transactivation by AP-1 is a molecular target of T cell clonal anergy. Science 257:1134-1138.

18. Koprak, S., M. J. Staruch, and F. J. Dumont. 1999. A specific inhibitor of the p38 mitogen activated protein kinase affects differentially the production of various cytokines by activated human T cells: dependence on CD28 signaling and preferential inhibition of IL-10 production. Cell. Immunol. 192:87-95.

19. Li, W., C. D. Whaley, A. Mondino, and D. L. Mueller. 1996. Blocked signal transduction to the ERK and JNK protein kinases in anergic CD4 ${ }^{+} \mathrm{T}$ cells. Science 271:1272-1276.

20. Lyons, A. B., and C. R. Parish. 1994. Determination of lymphocyte division by flow cytometry. J. Immunol. Methods 171:131-137.

21. Macian, F., F. Garcia-Cozar, S. H. Im, H. F. Horton, M. C. Byrne, and A. Rao. 2002. Transcriptional mechanisms underlying lymphocyte tolerance. Cell 109:719-731.

22. Migita, K. K. Eguchi, Y. Kawabe, T. Tsukada, Y. Ichinose, S. Nagataki, and 
A. Ochi. 1995. Defective TCR-mediated signaling in anergic T cells. J. Immunol. 155:5083-5087.

23. Miller, C., J. A. Ragheb, and R. H. Schwartz. 1999. Anergy and cytokinemediated suppression as distinct superantigen-induced tolerance mechanisms in vivo. J. Exp. Med. 190:53-64.

24. Mizuochi, T., S. Ono, T. R. Malek, and A. Singer. 1986. Characterization of two distinct primary $\mathrm{T}$ cell populations that secrete interleukin 2 upon recognition of class I or class II major histocompatibility antigens. J. Exp. Med. 163:603-619.

25. Munder, M., E. Bettelli, L. Monney, J. M. Slavik, L. B. Nicholson, and V. K. Kuchroo. 2002. Reduced self-reactivity of an autoreactive T cell after activation with cross-reactive non-self-ligand. J. Exp. Med. 196:1151-1162.

26. Numazawa, S., M. Watabe, S. Nishimura, M. Kurosawa, M. Izuno, and T. Yoshida. 2003. Regulation of ERK-mediated signal transduction by p38 MAP kinase in human monocytic THP-1 cells. J. Biochem. (Tokyo) 133: $599-605$.

27. Okamoto, N., K. Tezuka, M. Kato, R. Abe, and T. Tsuji. 2003. PI3-kinase and MAP-kinase signaling cascades in AILIM/ICOS- and CD28-costimulated T cells have distinct functions between cell proliferation and IL-10 production. Biochem. Biophys. Res. Commun. 310:691-702.

28. Powell, J. D., C. G. Lerner, G. R. Ewoldt, and R. H. Schwartz. 1999. The -180 site of the IL-2 promoter is the target of CREB/CREM binding in T cell anergy. J. Immunol. 163:6631-6639.

29. Raingeaud, J., S. Gupta, J. S. Rogers, M. Dickens, J. Han, R. J. Ulevitch, and R. J. Davis. 1995. Pro-inflammatory cytokines and environmental stress cause p38 mitogen-activated protein kinase activation by dual phosphorylation on tyrosine and threonine. J. Biol. Chem. 270:7420-7426.

30. Rammensee, H. G., R. Kroschewski, and B. Frangoulis. 1989. Clonal anergy induced in mature $\mathrm{VB} 6^{+} \mathrm{T}$ lymphocytes on immunizing Mls- ${ }^{\mathrm{b}}$ mice with Mls- $1^{\text {a }}$ expressing cells. Nature 339:541-544.

31. Samelson, L. E., R. N. Germain, and R. H. Schwartz. 1983. Monoclonal antibodies against the antigen receptor on a cloned T-cell hybrid. Proc. Natl. Acad. Sci. USA 80:6972-6976.

32. Sano, I., T. Takahashi, T. Koji, H. Udono, K. Yui, and H. Ayabe. 2001 Prolonged survival of rat cardiac allograft with proinflammatory cytokine inhibitor. J. Heart Lung Transplant. 20:583-589.

33. Schwartz, R. H. 2003. T cell anergy. Annu. Rev. Immunol. 21:305-334

34. Shibuya, H., K. Yamaguchi, Shirakabe, K., A. Tonegawa, Y. Gotoh, N. Ueno, K. Irie, E. Nishida, and K. Matsumoto. 1996. TAB1: an activator of the TAK1 MAPKKK in TGF- $\beta$ signal transduction. Science 272:1179-1182.

35. Singh, R. P., P. Dhawan, C. Golden, G. S. Kapoor, and K. D. Mehta. 1999 One-way cross-talk between p38(MAPK) and p42/44(MAPK). Inhibition of p38(MAPK) induces low density lipoprotein receptor expression through activation of the p42/44(MAPK) cascade. J. Biol. Chem. 274:19593-19600.

36. Sloan-Lancaster, A. S. J., Shaw, J. B. Rothbard, and P. M. Allen. 1994.
Partial T cell signaling: altered phospho- $\zeta$ and lack of zap70 recruitment in APL-induced T cell anergy. Cell 79:913-922.

37. Sundstedt, A., I. Hoiden, A. Rosendahl, T. Kalland, N. van Rooijen, and M. Dohlsten. 1997. Immunoregulatory role of IL-10 during superantigen-induced hyporesponsiveness in vivo. J. Immunol. 158:180-186.

38. Sundstedt, A., M. Sigvardsson, T. Leanderson, G. Hedlund, T. Kalland, and M. Dohlsten. 1996. In vivo anergized CD4 ${ }^{+}$T cells express perturbed AP-1 and NF-кB transcription factors. Proc. Natl. Acad. Sci. USA 93:979-984.

39. Takaesu, G., S. Kishida, A. Hiyama, K. Yamaguchi, H. Shibuya, K. Irie, J. Ninomiya-Tsuji, and K. Matsumoto. 2000. TAB2, a novel adaptor protein, mediates activation of TAK1 MAPKKK by linking TAK1 to TRAF6 in the IL-1 signal transduction pathway. Mol. Cell 5:649-658.

40. Tanchot, C., D. L. Barber, L. Chiodetti, and R. H. Schwartz. 2001. Adaptive tolerance of $\mathrm{CD}^{+} \mathrm{T}$ cells in vivo: multiple thresholds in response to a constant level of antigen presentation. J. Immunol. 167:2030-2039.

41. Telander, D. G., E. N. Malvey, and D. L. Mueller. 1999. Evidence for repression of IL-2 gene activation in anergic T cells. J. Immunol. 162:14601465 .

42. Tominaga, N., K. Ohkusu-Tsukada, H. Udono, R. Abe, T. Matsuyama, and K. Yui. 2003. Development of Th1 and not Th2 immune responses in mice lacking IFN-regulatory factor-4. Int. Immunol. 15:1-10.

43. Tzachanis, D., G. J. Freeman, N. Hirano, van Puijenbroek, A. A., M. W. Delfs, A. Berezovskaya, L. M. Nadler, and V. A. Boussiotis. 2001. Tob is a negative regulator of activation that is expressed in anergic and quiescent $\mathrm{T}$ cells. Nat. Immunol. 2:1174-1182.

44. Udono, H., T. Yamano, Y. Kawabata, M. Ueda, and K. Yui. 2001. Generation of cytotoxic T lymphocytes by MHC class I ligands fused to heat shock cognate protein 70. Int. Immunol. 13:1233-1242.

45. Utting, $\mathbf{O}$., S. J. Teh, and H. S. Teh. 2000. A population of in vivo anergized $\mathrm{T}$ cells with a lower activation threshold for the induction of CD25 exhibit differential requirements in mobilization of intracellular calcium and mitogen-activated protein kinase activation. J. Immunol. 164:2881-2889.

46. Westermarck, J., S. P. Li, T. Kallunki, J. Han, and V. M. Kahari. 2001. p38 mitogen-activated protein kinase-dependent activation of protein phosphatases 1 and 2A inhibits MEK1 and MEK2 activity and collagenase 1 (MMP-1) gene expression. Mol. Cell. Biol. 21:2373-2383.

47. Yui, K., S. Komori, M. Katsumata, R. M. Siegel, and M. I. Greene. 1990 Self-reactive T cells can escape clonal deletion in T-cell receptor V beta 8.1 transgenic mice. Proc. Natl. Acad. Sci. USA 87:7135-7139.

48. Yui, K., Y. Ishida, M. Katsumata, S. Komori, T. M. Chused, and R. Abe. 1993. Two separate mechanisms of T cell clonal anergy to Mls-1. J. Immunol. 151:6062-6075.

49. Zhang, X. H., Shi, M. Hampong, L. Blanis, and S. Pelech. 2001. Stressinduced inhibition of ERK1 and ERK2 by direct interaction with p38 MAP kinase. J. Biol. Chem. 276:6905-6908. 